\title{
Does the Geography Major Fit in STEM?
}

\author{
Md Rajibul Al Mamun ${ }^{1}$, Trisha Jackson ${ }^{1} \&$ George White ${ }^{1}$ \\ ${ }^{1}$ Department of Geography, South Dakota State University, Brookings, SD 57006, USA \\ Correspondence: Md Rajibul Al Mamun, Department of Geography, South Dakota State University, Brookings, \\ SD 57006, USA. Tel: 1-605-651-4982. E-mail: md.rajibul.almamun@jacks.sdstate.edu
}

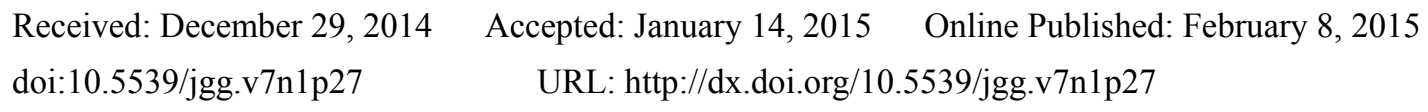

\begin{abstract}
STEM education plays a significant role in developing reasoning and technical skills among other benefits. Definitions of geography vary somewhat, but most of the sources define geography as a science. Geography relates to the STEM disciplines with application of geographical tools to solve problems. However, geography is not included as a STEM discipline by federal authorities in the United States (US). This paper presents evidence from US graduate and undergraduate geography programs demonstrating how geography qualifies as a STEM discipline, a qualification that could provide a variety of benefits for the programs and students alike. This research suggests that more than $50 \%$ of US colleges/universities confer Bachelor of Science (BS) or Master of Science (MS) degrees in geography and the distribution of these institutions occurs in most states. Therefore, geography has already been recognized as a STEM major by these US colleges/universities that offer STEM coursework including physical geography, Geographic Information System (GIS), remote sensing, natural resources, environmental science, and atmospheric science. Hence, it follows that government authorities should recognize geography as STEM.
\end{abstract}

Keywords: STEM, geography major, science, geographic education

\section{Introduction}

\subsection{Geography and STEM}

Geography strongly links the STEM (Science, Technology, Engineering, and Mathematics) disciplines with application of geographical technology/tools, which can provide a better understanding of cross-disciplinary phenomena to address important problems. However, geography is somewhat overlooked as a STEM field by government authorities (Dangermond, 2013). Misclassification of STEM majors, including geography, can detract from the concept of STEM. If a STEM field is classified as non-STEM, then both local and international students will be deprived of opportunities and benefits such as salary increases and work extensions. For immigration purposes, foreign scholars can also lose opportunities to obtain visas and work permits because policymakers emphasize hiring workers skilled in STEM areas from abroad. In a time when geographical science is poised to address overarching issues "to help society manage and adapt to the transformation of Earth's surface," (The National Academies, 2014) a federal classification of geography as STEM is overdue.

The federal government has two authorities who maintain lists of majors that are classified as STEM: the National Science Foundation (NSF) and the Department of Homeland Security (DHS). Unfortunately, geography is not listed in any of their STEM discipline lists. Thus, a chasm exists between the scientific practices and tools of geographers and how federal authorities classify geography majors. Here the authors explore this issue by considering the perspective of geography degree-granting institutions in the US. The degree requirements of these institutions help designate majors in geography that should be recognized as STEM majors by the federal authorities. By highlighting the lack of STEM classification for certain deserving geography majors, the authors hope to encourage a reorganization of the current NSF and DHS classification system. Appropriate classification of geography disciplines can have major impacts on the discipline, including but not limited to, increased funding opportunities, attraction of talented students, higher retention rates in STEM disciplines at the university level, and improved opportunities for foreign students.

The objective of this paper is to provide evidence to support federal policy change to gain STEM classification for qualifying majors in undergraduate and graduate programs. In order to provide a holistic picture of geographic higher education as it relates to STEM, the authors collected information on the types of geography 
degree programs offered in US colleges and universities. The authors make the assumption that BA and MA degrees generally emphasize language skills while BS and MS degrees generally emphasize science skills. The outcome of this research will support US authorities in policy updates and provide benefits to US geography programs, such as the likelihood for more funding opportunities. This process can be modelled by other countries that choose to participate in classifying STEM disciplines.

\subsection{Defining Geography as a Science}

Science is a methodical approach to studying the world. Science provides us with a way to present ideas that can be tested, repeated, and verified (McLelland, 2006). Science provides a way of solving a large class of important and practical problems. The problems with which science can deal include those in which the predominant factors are subject to the basic laws of logic and are typically measurable (Weaver, 1948). According to Richard Hartshorne (1958, p. 107), three dominant geography predecessors, Immanuel Kant, Alexander von Humboldt, and Alfred Hettner were in essential agreement in their view of the position and character of geography as a science. Therefore, the establishment of the discipline of geography as a science started early in the field of geography.

Definitions of geography vary somewhat, but all hold a common core (Table 1). According to Smith (1979), by seeking scientific laws and theories, by applying models and systems scientifically, or, at the very least, by testing hypotheses according to scientific criteria, geographers made geography a science. Alexander von Humboldt's many published works, especially the multi-volume Cosmos, which appeared in the mid-nineteenth century, sought to establish a systematic science of geography that could analyze the natural and the human worlds together and aspire to describe and explain all regions of the globe (Godlewska, 1999). By the end of the nineteenth century, the 'high-water mark' of European imperial expansion, geography had become "unquestionably the queen of all imperial sciences, inseparable from the domain of official and unofficial state knowledge" (Richards, 1993: 13).

Scholars continued to refine the definition of geography. According to MacKinder (1887), "I propose therefore to define geography as the science whose main function is to trace the interaction of man in society and so much of his environment as varies locally. If I were asked to describe geography roughly I should venture on the assertion that it is the science of distribution, the science, that is, which traces the arrangement of things in general on the earth's surface." Gritzner (2007) explores this notion by stating that "geography is the study of what, is where, why there, and why care?" The definition possesses several key attributes. It recognizes geography as a methodology, a unique way of organizing and analyzing information pertaining to the location, distribution, pattern, and interactions of the varied physical and human features of Earth's surface. Moreover, it acknowledges, like William Morris Davis ([1899] 1954), that geography is made of two halves: theoretical and practical. An antipathy is implied between theory and practice, for in geography, as in all sound scientific work, the two advance most amiably and effectively together. According to Downs (2010), the goal of William Morris Davis was to ensure "the full development of geography as a maturely organized science." Here the authors reiterate Davis' idea of geography by suggesting that geography be characterized as a STEM discipline.

Table 1. Partial list of geographers who classified geography as science

\begin{tabular}{ll}
\hline Geographers & Reference \\
\hline Immanuel Kant & Hartshorne (1958) \\
Alexander von Humboldt & Godlewska (1999), Hartshorne (1958) \\
William Morris Davis & Davis ([1899] 1954), Downs (2010) \\
Alfred Hettner & Hartshorne (1958) \\
Halford Mackinder & MacKinder (1887) \\
Neil Smith & Smith (1979) \\
Charles F. Gritzner & Gritzner (2007) \\
Thomas Richards & Richards (1993) \\
\hline
\end{tabular}

\section{Method (Supporting Evidence)}

In an attempt to estimate the number of programs that may be offering geography degrees deserving of STEM 
classification, the authors collected types of degrees being offered in US programs, focusing on Bachelor of Arts (BA), Bachelor of Science (BS), Master of Arts (MA), and Master of Science (MS). Data was collected from four sources, including "Geography Departments of North America," a webpage managed by Oklahoma State University (2013), websites of geography departments, through direct email communications with department officials, and from the Association of American Geographers (AAG) guide (Guide to Geography Programs in the Americas 2011-2012, 2012). In this data gathering mission, the authors also sought to determine characteristics of each bachelor's and master's degree where available, as an assumption that BA and MA degrees represent non-STEM majors while BS and MS degrees represent STEM majors. The authors acknowledge that this generalization does not always fit individual degree programs; it is just meant to gain a broad picture of the situation. Doctor of Philosophy (PhD) degrees were not a focus in this study because the title of these degrees does not generally indicate whether the degree is in a science or arts discipline.

During the data collection process, the authors concluded that if a college/university confers geography degrees in either BS or MS, the institution typically provides a program that would qualify as STEM. On the other hand, if a college/university confers geography degrees in either BA or MA, the program offered usually would not qualify as STEM. In cases where colleges/universities confer geography degrees both in BA \& BS and MA \& MS, then part of the geography program qualifies as STEM and part does not based on the institution's course content and research fields.

\section{Results}

After completing the data analysis, the authors found that 265 colleges/universities confer a bachelor's degree in geography and 142 colleges/universities confer a master's degree (Table 2, Figure 1a and 1b). Out of these, 54.7\% colleges/universities confer a BS degree and $57.7 \%$ colleges/universities confer a MS degree in geography. The high frequency of science degree offerings in geography demand consideration of this major as a STEM discipline.

Table 2. Types of degrees conferred in geography in US colleges/universities

\begin{tabular}{lllc}
\hline Degrees Conferred & Number of Colleges/Universities & Percent & Percent BS/MS \\
\hline BA & 120 & 45.3 & \\
BS & 44 & 16.6 & 54.7 \\
BA+BS & 101 & 38.1 & \\
MA & 60 & 42.3 & \\
MS & 53 & 37.3 & 57.7 \\
MA+MS & 29 & 20.4 & \\
\hline
\end{tabular}

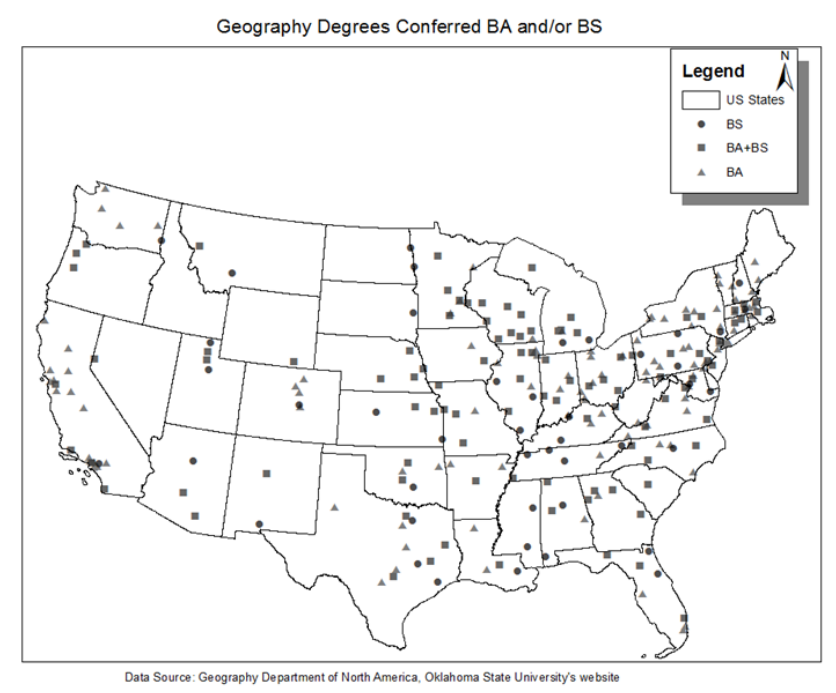

Figure 1a. Distribution (by institution) of types of geography degrees conferred as BA and/or BS 


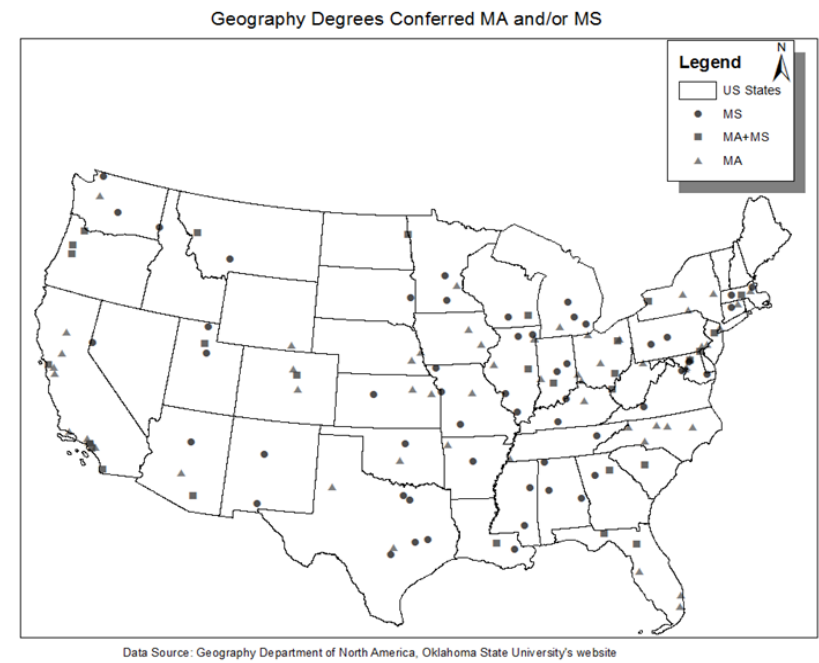

Figure 1b. Distribution (by institution) of types of geography degrees conferred as MA and/or MS

According to Figure 1a and $1 \mathrm{~b}$, geography degrees conferred as BS and MS are well distributed in the US, supporting the argument that geography should be considered a STEM field, not only at the state level, but also at the federal level. Both NSF and DHS are federal authorities, therefore, distribution across most states demands geography majors in the STEM federally. Other countries, such as the UK have already recognized geography as a part-STEM subject (http://www.gees.ac.uk/projtheme/stem/stem.htm).

\section{Discussion (Recommendation to NSF and DHS)}

Based on the evidence from the literature review and by highlighting the STEM nature of many geography programs in US colleges and universities, the authors hope to encourage a reorganization of the current NSF and DHS classification system. According to NSF STEM Classification of Instructional Programs (CIP) (http://wiscamp.engr.wisc.edu/forms/NSF-STEM-Classifications.pdf and https://www.lsamp.org/help/help_stem_cip_2010.cfm), geography is not listed as a STEM major. US colleges/universities confer geography degrees both in arts and science because of the multidisciplinary and interdisciplinary structure of how geographers approach the world; students typically take coursework emphasizing human/cultural aspects of geography (BA/MA) or the physical/technical aspects of the discipline (BS/MS). However, there are a few exceptions. Some liberal arts colleges including Carthage College, WI; Gustavus Adolphus College, MN; Macalester College, MN; Mount Holyoke College, MA; Ohio Wesleyan University, OH; and Vassar College, NY confer all of their STEM and non-STEM majors as BA (electronic mail communication with the departments, September 2-6, 2013). The geography programs in these liberal arts colleges have substantial science courses including GIS and physical geography. However, they confer only BA degrees because they do not have authorization to confer BS degrees.

The authors reviewed the research areas of the top ten geography programs based on National Research Council (NRC) rankings, 2010 (Appendix A). These sub-areas already considered as STEM by researchers because they relate to physical/technical (i.e., STEM) aspects:

- Physical Geography

- Biogeosciences, Climate \& Surface Processes, Ocean Processes

- Earth System Science

- Human-Environment Relations/Environment-Society Relations

- GIS, Remote Sensing

These sub-areas also should be considered as STEM even though they relate to human/cultural aspects because GIS and other geospatial technologies are being used in these sub-areas and, additionally, researchers in these areas also exercise scientific and numerical methodologies such as spatial analysis:

- Human Geography

- Cultural and Historical Geographies

- Globalization, Urban, Political and Economic Geographies 
Even though the US colleges/universities confer both BA/MA and BS/MS degrees, it is very difficult to distinguish sub-areas in geography as STEM and non-STEM. GIS, remote sensing and physical geography are classified as STEM by all researchers; however, the use of GIS, remote sensing, and data collection using GPS would not be something that stands alone. Geographers range from biogeographers and geomorphologists to historical geographers and economic geographers using geospatial technology as a tool. Additionally, graduate students use these same tools to accomplish in-depth statistical analysis in their theses/dissertations from physical geography to human geography. STEM-based government authorities, including NSF, fund geography programs (Appendix B). Therefore, the authors propose that NSF include the entire geography program as a STEM discipline.

Currently, the National Center for Education Statistics (NCES) Classification of Instructional Programs (CIP) code for Geography and Cartography is 45.07 with three subcategories (http://nces.ed.gov/IPEDS/CIPCODE/browse.aspx?y=55):

- 45.0701 (Geography)

- 45.0702 (Geographic Information Science and Cartography)

- 45.0799 (Geography, Other)

Geographic Information Science and Cartography (45.0702) is a category already recognized as a STEM major by DHS. Unfortunately, few US colleges/universities confer degrees in Geographic Information Science and Cartography. Most of the colleges/universities have GIS, Remote Sensing, and Cartography coursework/research areas within geography majors.

The authors recommend that the DHS consider the entirety of geography as a STEM major because most US Geography Departments offer STEM coursework including, but not limited to, GIS, remote sensing, natural resources, environmental science, atmospheric science, and meteorology. Furthermore, most research in Geography Departments in US colleges/universities is funded by government entities that promote STEM such as the National Aeronautics and Space Administration (NASA), National Science Foundation (NSF), United States Geological Survey (USGS), National Oceanic and Atmospheric Administration (NOAA), United States Department of Agriculture (USDA), and so forth (Appendix B).

Currently, international students in STEM fields in US colleges/universities receive a maximum of 29 months (12-months +17 -months extension) optional practical training (OPT) while a non-STEM graduates get only 12-month OPT. Therefore, many students in geography are deprived of this opportunity because Geography (CIP Code 45.0701) is not listed in the STEM list based on DHS criteria (http://www.ice.gov/sevis/stemlist.htm). For employment and immigration purposes, the federal government emphasizes the importance of STEM majors and, therefore, without recognition as STEM majors, both domestic and international students in geography become disqualified from certain opportunities. Therefore, to include geography in the STEM list will be a significant benefit to geography programs and students.

\section{Conclusions}

Many authors throughout the geography discipline's history have considered geography to be a STEM field. This research suggests more than 50\% US colleges/universities confer BS/MS degrees in geography and these institutions are well distributed, occurring in almost all states. So it follows that the NSF and DHS should recognize geography as a STEM major. Geography departments will benefit from this reclassification by attracting more students interested in entering a STEM field. Further delays in classifying geography as a STEM field only hurts the US in terms of competitiveness and innovation in STEM fields. Inclusion of geography programs as STEM by US Federal authorities will encourage other countries that are planning to classify STEM disciplines to include geography in the STEM list. Moreover, if a geography degree receives federal recognition as STEM, there will likely be more opportunities for funding and programs will attract more domestic and international students wishing to join a STEM discipline.

\section{Acknowledgments}

The authors would like to thank faculty and graduate students of the Geography Department of South Dakota State University who provided comments in this paper, department chairs from other geography programs who provided information about their departments, and professors in many geography programs who shared their ideas including Dr. Mona Domosh, President of AAG, 2014-15.

\section{References}

Dangermond, J. (2013). GIS is STEM! Retrieved October 23, 2013, from 
http://blogs.esri.com/esri/esri-insider/2013/01/02/gis-is-stem/

Davis, W. M. ([1899] 1954). The Geographical Cycle. Geographical Journal, 14, 481-504. Reprint in Geographical Essays, edited by Douglas Wilson Johnson. New York: Dover Publications.

Downs, R. M. (2010). Popularization of Geography: An Inseparable Relationship. Annals of the Association of American Geographers, 100 (2/April), 444-467. http://dx.doi.org/10.1080/00045601003638774

Godlewska, A. (1999). From Enlightenment vision to modern science: Humboldt's visual thinking. In D. Livingstone, \& C. Withers (Eds.), Geography and Enlightenment (pp. 236-75). Chicago, IL: University of Chicago Press.

Gritzner, C. F. (2007). What Is Where, Why There, and Why Care? Journal of Geography, 101(1), 38-40. http://dx.doi.org/10.1080/00221340208978465

Guide to Geography Programs in the Americas 2011-2012. (2012). Retrieved October 23, 2013, Retrieved from http://www.aag.org/galleries/publications-files/Guide.pdf

Hartshorne, R. (1958). The Concept of Geography as a Science of Space, from Kant and Humboldt to Hettner. Annals of the Association of American Geographers, 48 (2/June), 97-108. http://dx.doi.org/10.1111/j.1467-8306.1958.tb01562.x

MacKinder, H. J. (1887). On the Scope and Methods of Geography. The Royal Geographical Society, 9, 141-174. http://dx.doi.org/10.2307/1801248

McLelland, C. V. (2006). The Nature of Science and the Scientific Method. The Geological Society of America.

Oklahoma State University. (2013). Retrieved October 24, 2013, from http://www.ocgi.okstate.edu/geogdept/listing.htm

Richards, T. (1993). The Imperial Archive: Knowledge and the Fantasy of Empire. London: Verso.

Smith, N. (1979). Geography, Science and Post-positivist Modes of Explanation. Progress in Human Geography, 3, 356-383.

The National Academies. (2014). Retrieved July 29, 2014, from http://www8.nationalacademies.org/onpinews/newsitem.aspx?RecordID=12860

Weaver, W. (1948). Science and Complexity. Rockefeller Foundation, New York City.

\section{Appendix A}

\section{Research Areas}

Research Areas in Geography - top ten universities based on National Research Council (NRC) Ranking, 2010 (http://geog.umd.edu/sites/geog.umd.edu/files/NRCrankings.pdf)

\begin{tabular}{|c|c|}
\hline Universities (website) & Research Areas in geography \\
\hline $\begin{array}{l}\text { Boston University } \\
\text { (http://www.bu.edu/earth/research/) }\end{array}$ & $\begin{array}{ll}\text { - } & \text { Biogeosciences, Climate \& Surface Processes } \\
\text { - } & \text { Energy, Environment \& Society } \\
\text { - } & \text { Geographical Sciences } \\
\text { - } & \text { Geology, Geochemistry \& Geophysics }\end{array}$ \\
\hline $\begin{array}{l}\text { University of California Santa Barbara } \\
\text { (http://www.geog.ucsb.edu/people/faculty/) }\end{array}$ & $\begin{array}{ll}\text { - } & \text { Biogeosciences } \\
\text { - } & \text { Climate } \\
\text { - } & \text { Cognitive and Behavioral Geography } \\
\text { - } & \text { Geographic Information Science } \\
\text { - } & \text { Human-Environment Relations } \\
\text { - } & \text { Ocean Processes } \\
\text { - } & \text { Remote Sensing } \\
\text { - } & \text { Transportation }\end{array}$ \\
\hline $\begin{array}{l}\text { University of Maryland } \\
\text { (http://www.geog.umd.edu/landing/ }\end{array}$ & - Geospatial-Information Science and Remote Sensing \\
\hline
\end{tabular}




\begin{tabular}{|c|c|}
\hline Research) & $\begin{array}{l}\text { - Human Dimensions of Global Change - Coupled Human and } \\
\text { Natural Systems } \\
\text { - } \quad \text { Land Cover - Land Use Change } \\
\text { - } \quad \text { Carbon, Vegetation Dynamics and Landscape-Scale Processes }\end{array}$ \\
\hline $\begin{array}{l}\text { University of Colorado at Boulder } \\
\text { (http://geography.colorado.edu/research/dept_t } \\
\text { hemes) }\end{array}$ & $\begin{array}{ll}\text { - } & \text { Physical Geography } \\
\text { - } & \text { Human Geography } \\
\text { - } & \text { Environment-Society Relations } \\
\text { - } & \text { Geographic Information Science }\end{array}$ \\
\hline $\begin{array}{l}\text { University of Wisconsin-Madison } \\
\text { (http://www.geography.wisc.edu/faculty/facult } \\
\text { y-speciality.php) }\end{array}$ & $\begin{array}{ll}\text { - } & \text { Physical Geography } \\
\text { - } & \text { People-Environment Geography } \\
\text { - } & \text { Cartography and GIS } \\
\text { - } & \text { Human Geography } \\
\text { - } & \text { Area Studies }\end{array}$ \\
\hline $\begin{array}{l}\text { University of California Los Angeles } \\
\text { (http://www.geog.ucla.edu/research.php) }\end{array}$ & $\begin{array}{ll}\text { - } & \text { Biogeographic Processes } \\
\text { - } & \text { Cultural and Historical Geographies } \\
\text { - } & \text { Earth Systems Science } \\
\text { - } & \text { Globalization, Urban, Political and Economic Geographies } \\
\text { - } & \text { Population Movement and Flows } \\
\text { - } & \text { Geographies of Nature and Society } \\
\text { - } & \text { Hydrological and Geomorphological Processes } \\
\text { - } & \text { Geographic Methods and Techniques }\end{array}$ \\
\hline $\begin{array}{l}\text { Penn State University } \\
\text { (http://www.geog.psu.edu/) }\end{array}$ & $\begin{array}{ll}\text { - } & \text { GIScience } \\
\text { - } & \text { Human Geography } \\
\text { - } & \text { Nature/Society } \\
\text { - } & \text { Physical Geography }\end{array}$ \\
\hline $\begin{array}{l}\text { Clark University } \\
\text { (http://www.clarku.edu/departments/geograph } \\
\text { y/graduate/index.cfm) }\end{array}$ & $\begin{array}{ll}\text { - } & \text { Nature-society geography } \\
\text { - } & \text { Urban-economic geography } \\
\text { - } & \text { Geographic information science } \\
\text { - } & \text { Earth System Science }\end{array}$ \\
\hline $\begin{array}{l}\text { University of California Berkeley } \\
\text { (http://geography.berkeley.edu/undergrad/prog } \\
\text { ram.php) }\end{array}$ & $\begin{array}{ll}\text { - } & \text { Basic Physical Geography } \\
\text { - } & \text { World Geography } \\
\text { - } & \text { Regional Geographies } \\
\text { - } & \text { Earth System Science } \\
\text { - } & \text { Economy, Culture \& Society } \\
\text { - } & \text { Methodology }\end{array}$ \\
\hline $\begin{array}{l}\text { Arizona State University } \\
\text { (http://geoplan.asu.edu/gradgeography) }\end{array}$ & $\begin{array}{ll}\text { - } & \text { Computational Spatial Science } \\
\text { - } & \text { Cultural Geographies_-Place, Culture, Identity } \\
\text { - } & \text { Earth Systems \& Climate Science } \\
\text { - } & \text { Sustainability Science \& Studies }\end{array}$ \\
\hline
\end{tabular}

\section{Appendix B}

\section{Research Funding Sources}


Funding sources of Research Projects in geography programs - four out of top ten programs based on NRC Ranking, 2010 (data was collected from websites on October 23, 2013)

\begin{tabular}{|l|c|c|c|c|c|}
\hline Research Projects in geography programs & NASA & NSF & USGS & NOAA & USDA \\
\hline $\begin{array}{l}\text { University of California Santa Barbara } \\
\text { (http://www.geog.ucsb.edu/research/grants-awarded/) }\end{array}$ & 6 & 11 & 1 & - & 1 \\
\hline $\begin{array}{l}\text { University of Maryland } \\
\text { (http://www.geog.umd.edu/landing/Research) }\end{array}$ & 28 & 4 & 1 & - & 1 \\
\hline $\begin{array}{l}\text { Clark University } \\
\text { (http://www.clarku.edu/departments/geography/research/grants.cfm) }\end{array}$ & 5 & 13 & - & 1 & 1 \\
\hline Arizona State University (http://geoplan.asu.edu/research/projects) & - & 27 & - & 1 & 1 \\
\hline
\end{tabular}

\section{Copyrights}

Copyright for this article is retained by the author(s), with first publication rights granted to the journal.

This is an open-access article distributed under the terms and conditions of the Creative Commons Attribution license (http://creativecommons.org/licenses/by/3.0/). 